\title{
The $387 \mathrm{~kb}$ linear plasmid pPZG101 of Streptomyces rimosus and its interactions with the chromosome
}

\author{
Birgit Gravius, ${ }^{1}$ Digna Glocker, ${ }^{1}$ Jasenka Pigac, ${ }^{2}$ Kenan Pandža, ${ }^{1}$ \\ Daslav Hranueli² and John Cullum ${ }^{1}$
}

\author{
Author for correspondence: John Cullum. Tel: +496312054062. Fax: +496312054090. \\ e-mail: cullum@rhrk.uni-kl.de
}

\footnotetext{
1 LB Genetik, Universität Kaiserslautern, Postfach 3049, D-67653 Kaiserslautern, Federal Republic of Germany

2 PLIVA Research Institute, Zagreb, Republic of Croatia
}

\begin{abstract}
The linear plasmid pPZG101 of Streptomyces rimosus R6 was restriction mapped with the enzymes Asel, Bfrl, Dral and Xbal. It is 387 kb in size and the ends are inverted repeats of at least $95 \mathrm{~kb}$ in length. Twenty spontaneous morphological variants and seventeen auxotrophic mutants were screened for changes in the plasmid. Two strains were found that had lost all plasmid sequences. Four strains had integrated parts of the plasmid into the chromosome. Restriction analysis suggested that at least three of the integrated strains had retained free plasmid ends. If it is assumed that the chromosome of $S$. rimosus $\mathrm{R} 6$ is linear, this might be explained by replacement of one or both chromosome ends by a plasmid end. One strain, which overproduced oxytetracycline, carried an enlarged linear plasmid of $1 \mathrm{Mb}$ in size that had acquired chromosomal sequences from the oxytetracycline biosynthesis cluster.
\end{abstract}

Keywords: Streptomyces rimosus, linear plasmid, oxytetracycline biosynthesis genes, plasmid prime

\section{INTRODUCTION}

Linear plasmids are common in Streptomyces (Kinashi et al., 1987; Hershberger et al., 1989). In the bestinvestigated cases, the ends are inverted repeats and have a protein bound to the $5^{\prime}$ ends of the DNA (Hirochika et al., 1984; Keen et al., 1988; Kinashi \& Shimaji-Murayama, 1991; Chen et al., 1993), which is thought to act as a primer for replication (Salas, 1991). Sakaguchi (1990) has defined a class of elements with inverted repeats at their ends called invertrons, which includes linear plasmids, Bacillus phage $\phi 29$, adenovirus and yeast killer plasmids. The terminal inverted repeats in Streptomyces plasmids vary between $44 \mathrm{bp}$ and over $80 \mathrm{~kb}$ (Chen et al., 1993; Kinashi et al., 1991). Linear plasmids of sizes between $12 \mathrm{~kb}$ and over $500 \mathrm{~kb}$ have been reported in Streptomyces (Keen et al., 1988; Kinashi et al., 1987). The designation 'giant linear plasmid' is often used to describe the larger linear plasmids; however, there is no evidence for any essential differences between such large plasmids and smaller linear plasmids.

Abbreviations: OTC, oxytetracycline; PFGE, pulsed-field gel electrophoresis.
The sex factor SCP1 of Streptomyces coelicolor A3(2), which is a linear plasmid of about $350 \mathrm{~kb}$ (Kinashi \& ShimajiMurayama, 1991), can integrate into the chromosome (Vivian \& Hopwood, 1973). Analysis of one integrant showed that most of SCP1 was present, but that the free ends had been lost (Hanafusa \& Kinashi, 1992). SCP1' plasmids carrying various chromosomal genes have also been reported (Hopwood \& Wright, 1976). SCP1 carries genes for biosynthesis of the antibiotic methylenomycin (Wright \& Hopwood, 1976), but in other linear plasmids in Streptomyces there is little evidence for the encoding of antibiotic biosynthesis genes.

Streptomyces rimosus is used commercially to produce oxytetracycline, and genetic studies have been carried out by several laboratories. Linear plasmids have been detected in three $S$. rimosus strains (Chardon-Loriaux et al., 1986; Rathos et al., 1989; Cullum et al., 1991). In the last case, we reported the presence of a linear plasmid in $S$. rimosus $\mathrm{R} 6$, a strain where a variety of genetic markers and a genetic map are available (Alačević et al., 1978). It is unknown whether this plasmid, which we have named pPZG101, plays a role in conjugational fertility. In another $S$. rimosus strain conjugational fertility has been attributed to two genetically identified plasmids, SRP1 
(Friend et al., 1978) and SRP2; the existence of SRP2' plasmids carrying oxytetracycline (OTC) resistance gene(s) was also reported (Rhodes et al., 1984). Two resistance genes have been reported in this strain; they flank the $24 \mathrm{~kb}$ biosynthesis gene cluster (Butler et al., 1989; Binnie et al., 1989).

In this paper, we report the restriction map of the linear plasmid pPZG101 in S. rimosus R6 and the presence of homologous plasmids in two other $S$. rimosus strains. We also screened various classes of mutants to detect interaction of the plasmid with the chromosome (i.e. integration or prime formation).

\section{METHODS}

Strains, media and culture conditions. Streptomyces rimosus R6 derivatives were obtained from the culture collection of the PLIVA Research Institute, Zagreb. The auxotrophic mutant strains $127,235,502,521,531,570,584,586,596,601,605,609$, 612,613 and 615, which are all derivatives of the parent strain 65, are described by Pigac \& Alačević (1979). Strains 554 and 593 (this study) are MNNG-induced riboflavin-requiring (rib12) and thymine-requiring (thy-5) auxotrophic derivatives of strain 500 (Gravius et al., 1993). The 20 spontaneous morphological variants used were all the variants studied by Gravius et al. (1993), with the exception of MV3 and MV32, which were omitted because of their high reversion frequencies. S. rimosus strain R7 (ATCC 10970) was obtained from the American Type Culture Collection. S. rimosus strain M4018 (Butler et al., 1989) and GLW220 (a derivative in which the whole OTC cluster is carried on the genetically-defined plasmid SRP2 as an SRP2', lain Hunter, personal communication) were kindly provided by Iain Hunter, University of Glasgow, UK. Plasmid pGLW106, which carries the $\operatorname{otr} A$ gene on a $2.5 \mathrm{~kb} B g / \mathrm{II}-\mathrm{BamHI}$ fragment (Butler et al., 1989) cloned into plasmid pPFZ34, was kindly provided by Iain Hunter. Eschericbia coli HB101(pUT1954) (Reynes et al., 1988) was used as a source of the $\operatorname{otr} B$ gene for DNA hybridization.

Methods for propagation and maintenance of Streptomyces stocks, and the complete agar medium (CM) (Hranueli et al., 1979), minimal agar medium (MM) (Alačević et al., 1973) and the complete pre-cultivation liquid medium (CPM) (Pigac $e t$ al., 1982) used, were described previously.

DNA manipulation. Total DNA from Streptomyces strains was isolated using the 'Kirby mix' method (Hopwood et al., 1985). Plasmid DNA from E. coli was purified by caesium chloride/ ethidium bromide gradient centrifugation (Sambrook et al., 1989). DNA digestion with restriction enzymes, agarose gel electrophoresis, Southern blotting, labelling of DNA probes with digoxigenin, hybridization and detection of bands were carried out as described by Gravius et al. (1993).

Pulsed-field gel electrophoresis (PFGE). DNA was prepared from mycelium immobilized in agarose blocks as described by Gravius et al. (1993). Restriction digests were carried out with AseI (Biolabs), BfrI (Boehringer), DraI (Biolabs) and XbaI (Pharmacia) using the enzyme supplier's recommended buffer. A Bio-Rad CHEF DRII gel apparatus was used with running conditions selected to give optimal resolution in the molecular mass regions of interest (see figure legends). Saccharomyces cerevisiat chromosomes or lambda ladders were used routinely as markers. However, the sizes for fragments under $500 \mathrm{~kb}$ were recalculated using a correction for the high $\mathrm{G}+\mathrm{C}$ content based on ladders of the $S$. rimosus phages RP2 and RP3 (Gravius et al., 1994). Linear plasmid DNA was prepared by running un- digested total DNA in a low-melting-point agarose (Incert agarose, FMC Biozym) gel in $1 \times$ TAE $(0.04 \mathrm{M}$ Tris/acetate, $0.001 \mathrm{M}$ EDTA, pH 8.0) buffer, using $200 \mathrm{~V}$ for $20 \mathrm{~h}$ with a ramped pulse time of $60-100 \mathrm{~s}$. For preparation of probes, the whole gel was stained in ethidium bromide and slices of gel containing plasmid DNA were cut out. The DNA was purified by melting and phenol extraction (Sambrook et al., 1989). When the DNA was to be digested, the appropriate gel slices were identified by staining one track with ethidium bromide. The gel slices were then incubated in $300 \mu$ lof the appropriate restriction buffer at $4{ }^{\circ} \mathrm{C}(2 \times 3 \mathrm{~h})$. Digestion was performed using $200 \mu \mathrm{l}$ buffer and $100 \mathrm{U}$ restriction enzyme for $24 \mathrm{~h}$ at $37^{\circ} \mathrm{C}$.

\section{RESULTS}

\section{Restriction mapping of the plasmid}

Previous work had shown the presence of a plasmid DNA molecule in S. rimosus $\mathrm{R} 6-500$ that migrated in pulsed-field gels like a linear molecule of about $370 \mathrm{~kb}$ (Cullum et al., 1991). The plasmid DNA was sensitive to exonuclease III (B. Gravius, unpublished results), which also supported the presence of a linear molecule. DNA of the linear plasmid was isolated by running undigested total DNA of $S$. rimosus $\mathrm{R} 6$ on a low-melting-point agarose pulsed-field gel and excising the gel slices containing the plasmid band. These slices were digested with the rarely cutting restriction enzymes AseI, BfrI, DraI and $X b a \mathrm{I}$ and subjected to PFGE (Fig. 1a). Initially, difficulties were encountered in mapping the plasmid because of a systematic error due to the faster migration of $\mathrm{G}+\mathrm{C}$-rich fragments than lambda DNA ladder fragments of equivalent size; this problem was solved by use of $\mathrm{G}+\mathrm{C}$-rich markers (see Methods). Dral gave two fragments of

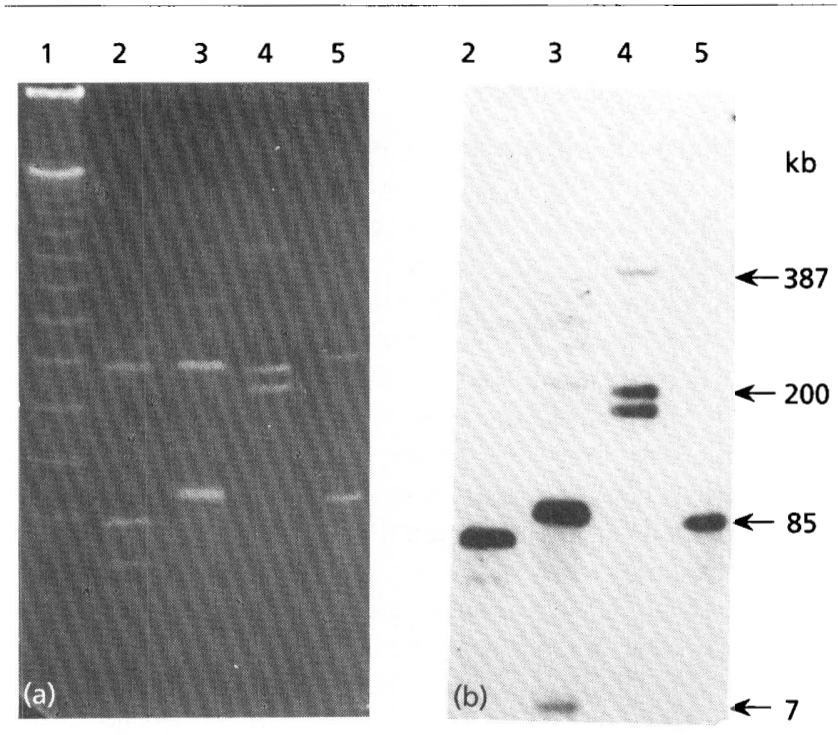

Fig. 1. (a) Restriction digests of pPZG101. Gel slices containing plasmid DNA were digested with different restriction enzymes and subjected to a second round of PFGE. 1, lambda ladder, 2, Asel, 3, Bfrl, 4, Dral, 5, Xbal. The pulse programme was $24 \mathrm{~h}$, ramp of pulse times 3-40 s. (b) Southern transfer of the gel from (a) hybridized with digoxigenin-labelled DNA from the Asel-B fragment of pPZG 101. Detection by light emission. 

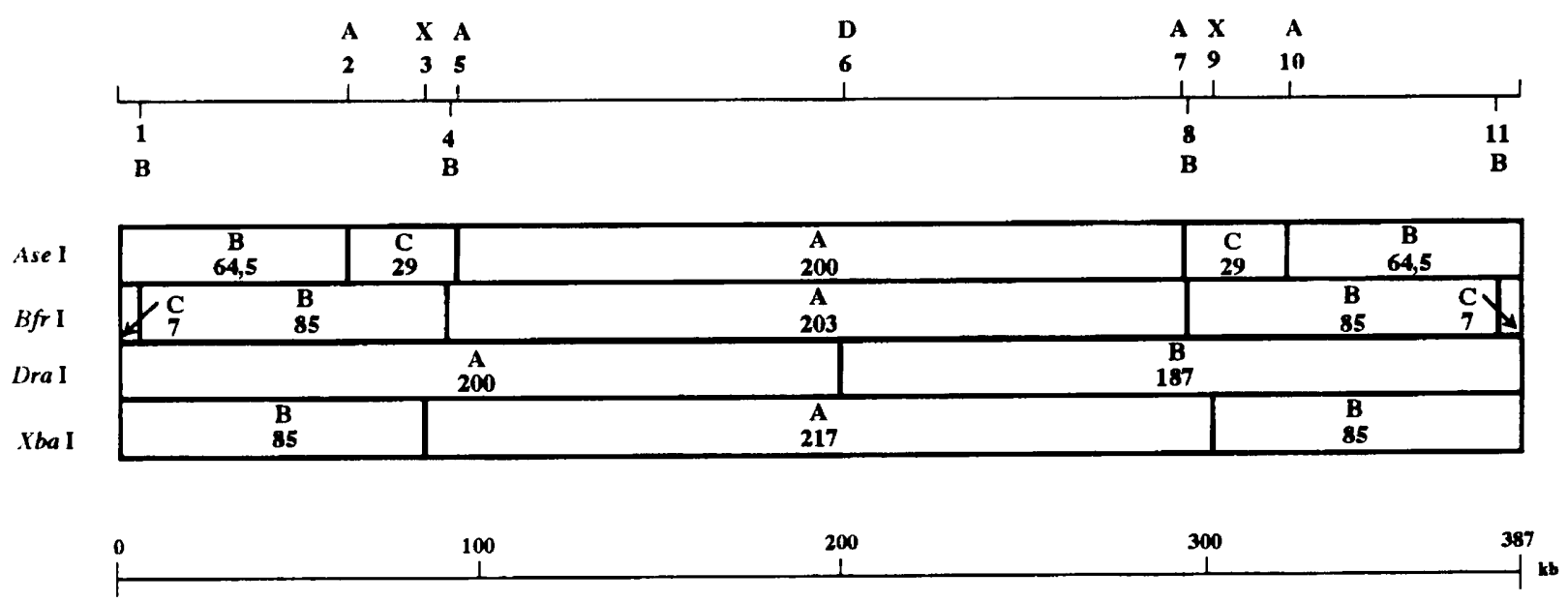

Fig. 2. Restriction map of $\mathrm{PPZG101}$. In the linear map (upper part of figure) the 11 restriction sites are numbered and the enzymes are indicated by: A (Asel), B (Bfrl), D (Dral) and X (Xbal). In the block diagram (central part of figure) the restriction fragments are denoted by letters and the sizes are given in $\mathrm{kb}$.

$200 \mathrm{~kb}$ and $187 \mathrm{~kb}$ (Fig. 1a, track 4), whose sum is the size of the undigested plasmid; there was an additional weak band of $387 \mathrm{~kb}$ visible corresponding to undigested plasmid. Thus, there is a single DraI site in the plasmid.

The other three enzymes gave either two or three fragments, whose sum was less than that of the size of the undigested plasmid. Double digests of these enzymes with DraI (data not shown) revealed that the unique DraI site was within the largest restriction fragment in each case. The simplest explanation for the discrepancies in the sums of the sizes of restriction fragments is that the smaller fragments were present as double bands. This was supported by the following experiments.

The three AseI fragments are of sizes $200 \mathrm{~kb}, 64.5 \mathrm{~kb}$ and $29 \mathrm{~kb}$ respectively (Fig. 1a, track 2). The $64.5 \mathrm{~kb}$ AseI-B band was eluted from a gel, labelled with digoxigenin and used as a hybridization probe against a Southern transfer of a gel with restriction digests with the four enzymes (Fig. 1b). Both DraI fragments hybridized strongly (Fig. 1b, track 4), compatible with the idea that the AseI-B band was a doublet. Similarly, the AseI-C fragment also hybridized to both DraI fragments (data not shown). A partial AseI digest (data not shown) contained additional fragments of about $95 \mathrm{~kb}$ and $230 \mathrm{~kb}$, which were interpreted as fusions of the AseI-B + C and AseI-A + C bands respectively. This suggested the AseI map in Fig. 2, with long terminal inverted repeats of over $90 \mathrm{~kb}$.

Xbal gave two fragments, of $217 \mathrm{~kb}$ and $85 \mathrm{~kb}$ (Fig. 1a, track 5). The Ase I-B fragment hybridized to the $85 \mathrm{~kb}$ Xbal fragment (Fig. 1b, track 5). Double digests with Ase I and XbaI (data not shown) located the XbaI sites within the $29 \mathrm{~kb}$ Asel-C fragment, confirming the positions shown in the map (Fig. 2).

Digests with BfrI gave a similar pattern to those with XbaI (Fig. 1a, track 3), but showed an additional weak partial digest band corresponding in size to a fusion of the
$B f r \mathrm{I}-\mathrm{A}+\mathrm{B}$ fragments. The AseI-B fragment hybridized to the $B f r I-B$ fragment, but also revealed an additional BfrI$C$ fragment of $7 \mathrm{~kb}$ (Fig. 1b, track 3), which was not visible in the gel (Fig. 1a, track 3). An AseI-BfrI double digest (data not shown) localized the BfrI site in the AseI$C$ fragment. These data gave the map for AseI, BfrI, DraI and $X b a I$ shown in Fig. 2.

\section{Strains lacking a cytoplasmic linear plasmid}

Twenty spontaneous variants isolated during a study on genetic instability (Gravius et al., 1993) were screened by PFGE for loss of pPZG101 plasmid molecules. One of the variants (MV25) had lost the plasmid band (see Fig. 5a, track 3). A further variant (MV17) contained a larger plasmid (see Fig. 5a, track 4) that will be described further below.

When AseI digests were carried out with the original $S$. rimosus R6 strain, after a prerun to remove the plasmid DNA, a Southern blot showed no hybridization with pPZG101 (data not shown), indicating that the R6 chromosome had no homology to PPZG101. In contrast, restriction digests of total DNA of MV25 (not subjected to a prerun) showed hybridization with DNA of pPZG101 (Fig. 3b, tracks 4,6 and 8). This, and the lack of a visible plasmid in undigested MV25 samples, suggested that the plasmid had integrated into the chromosome of MV25. Comparison of AseI digests of MV25 with the parent strain (Fig. 3b, tracks 3 and 4) shows that bands indistinguishable in size from the AseI-B and AseI-C fragments are still present in MV25. Further restriction digests showed that both the BfrI-B and BfrI-C fragments (Fig. 3, tracks 5 and 6) and the XbaI-B fragment (tracks 7 and 8) seem to be conserved in MV25. Thus, for all three restriction enzymes, the fragments of the plasmid which make up the long inverted terminal repeats (Fig. 2) seem to be retained in MV25; these data suggest strongly that 


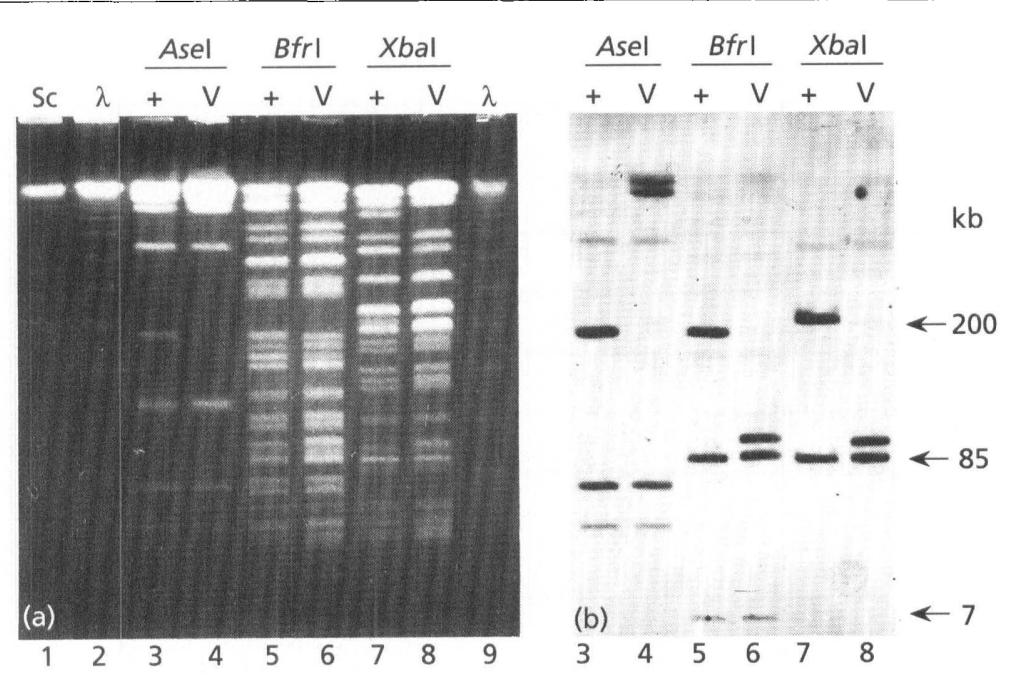

Fig. 3. (a) PFGE of total DNA from parent strain S. rimosus $\mathrm{R} 6-500 \quad(+)$ and spontaneous variant MV25 (V) digested with the restriction enzymes indicated. Sc, $S$. cerevisiae chromosomes; $\lambda$, lambda ladder. The pulse programme was $30 \mathrm{~h}$, ramp of pulse times 4-35s. (b) Southern transfer of the gel of (a) hybridized with digoxigeninlabelled DNA from pPZG101. (a)

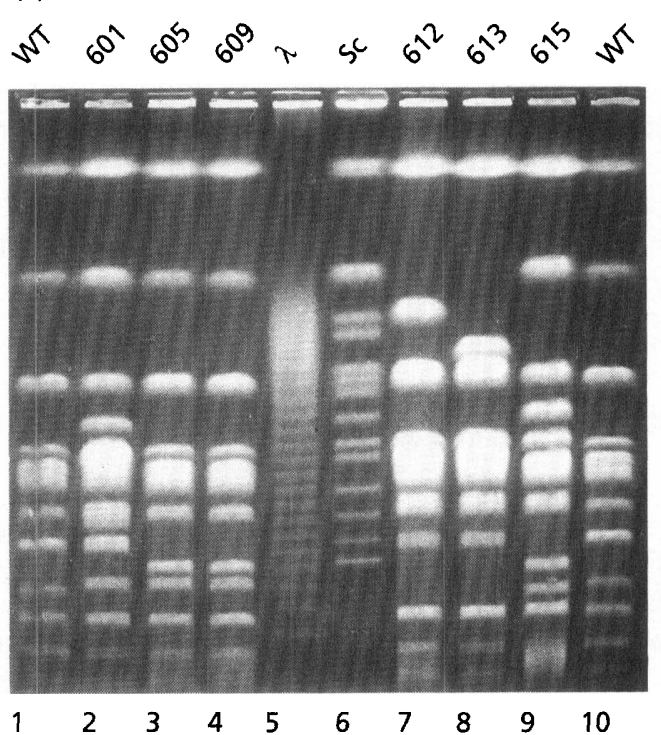

(b)

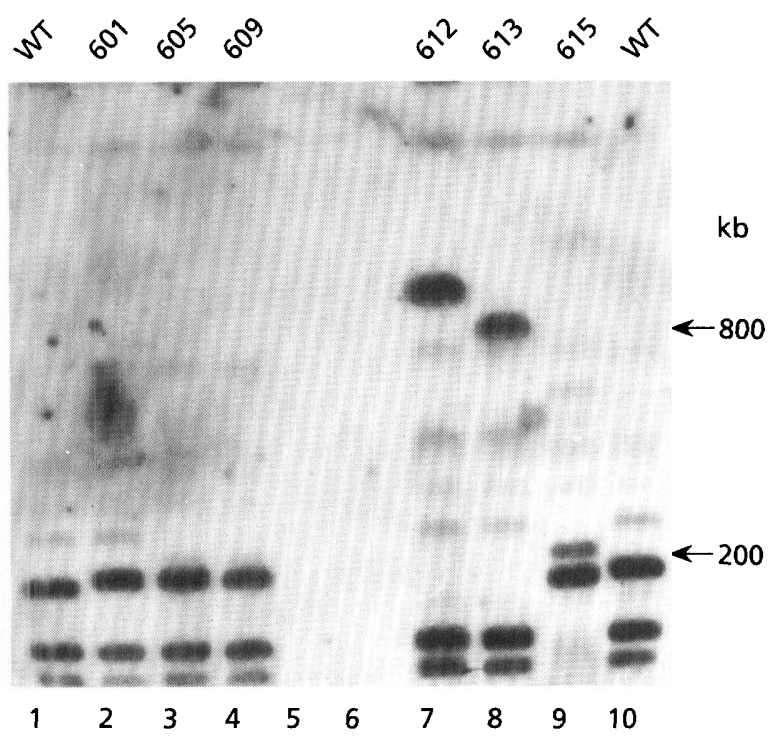

Fig. 4. (a) PFGE analysis of Asel-digested DNA of mutants. WT, S. rimosus R6-500 parent strain; $\lambda$, lambda ladder; Sc, $S$. cerevisiae chromosomes. The pulse programme was $28 \mathrm{~h}$, ramp of pulse times 60-130 s. (b) Southern transfer of the gel of (a) hybridized with digoxigenin-labelled DNA from pPZG101.

at least one free plasmid end is present in the integrated form. However, for each enzyme, the largest (central) fragment is not conserved in MV25. In the cases of BfrI and $X b a \mathrm{I}$ a single new fragment of $100 \mathrm{~kb}$ appears (Fig. $3 \mathrm{~b}$, tracks 6 and 8), whereas two new fragments of $690 \mathrm{~kb}$ and $480 \mathrm{~kb}$ are seen in AseI digests (track 4; the size estimates were obtained from a gel using a pulse program to resolve higher molecular mass fragments; data not shown).

Seventeen auxotrophic mutant strains were also screened and five of them did not contain a plasmid band. Total DNA of these strains was analysed with AseI and XbaI, as for MV25 (data not shown). Two of the strains R6-554 (rib-12) and R6-593 (tby-5) showed no hybridization with a pPZG101 probe, proving total loss of the plasmid. The other three strains, R6-612 (tty-2 pan-2 otc-187), R6-613 (tty-2 pan-2 otc-188) and R6-615 (bis-9 pan-2 otc-190), showed hybridizing fragments (Fig. 4b, tracks 7, 8, 9), suggesting plasmid integration into the chromosome. R6612 and R6-613 resembled MV25 in that the fragments corresponding to the plasmid ends seemed to be conserved (i.e. AseI-B, AseI-C; Fig. 4b, tracks 7 and 8; XbaI$\mathrm{B}$, data not shown). The fourth strain, 615, showed a different hybridization pattern lacking the Ase I-B and AseI-C fragments (Fig. 4b, track 9). All four integrated 
(a)

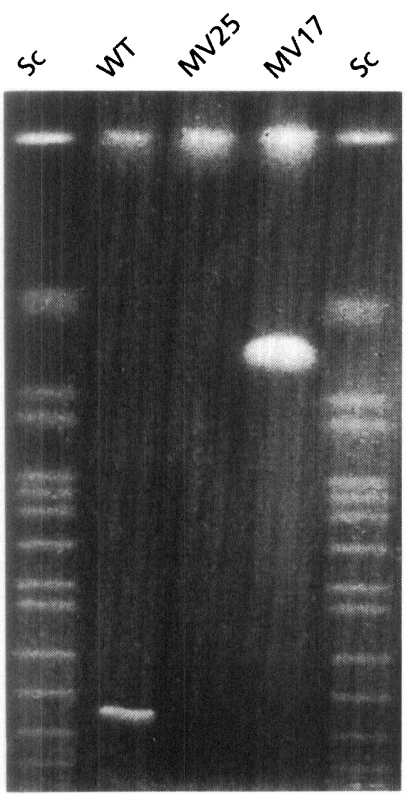

$\begin{array}{lllll}1 & 2 & 3 & 4 & 5\end{array}$ (b)

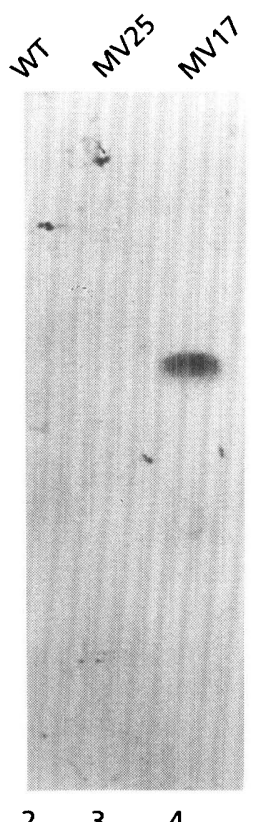

(c)

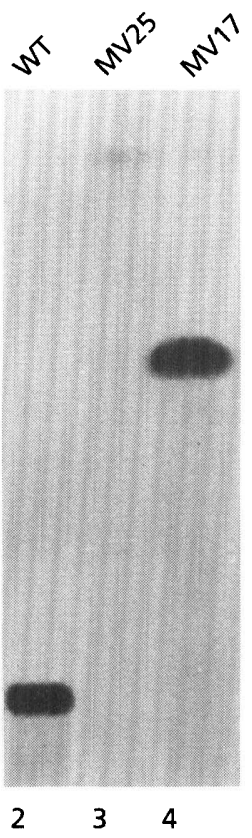

Fig. 5. (a) PFGE analysis of undigested DNA of spontaneous variants. Sc, S. cerevisiae chromosomes; WT, S. rimosus R6-500 parent strain. The pulse programme was $32 \mathrm{~h}$, ramp of pulse times 60-100 s. (b) Southern transfer of the gel from (a) hybridized with an otrB probe. (c) Southern transfer of the gel from (a) hybridized with digoxigeninlabelled pPZG101 DNA. strains showed different $A s e \mathrm{I}$ restriction patterns from each other.

While examining the auxotrophic mutants, it was noticed that the plasmid was smaller than in the isolate used for restriction mapping (Fig. 2). All the auxotrophic mutants with cytoplasmic plasmid were derivatives of R6-65 and it is likely that an increase in the size of the plasmid has occurred between R6-65 and the newer derivative R6-500. We named this smaller plasmid pPZG102 (as present in strain 601). In AseI digests, pPZG102 shows an AseI-A fragment of $213 \mathrm{~kb}$ (Fig. 4, tracks $2,3,4$ ), which is slightly larger than that in pPZG101 (track 1). This would be explained if pPZG102 did not carry long inverted repeats, i.e. it would have only two AseI sites, generating three single fragments.

\section{A derivative of the linear plasmid carrying OTC genes}

One variant strain (MV17) carried a plasmid DNA molecule (named PPZG103) of about $1 \mathrm{Mb}$ instead of the $387 \mathrm{~kb}$ pPZG101 (Fig. 5a, track 4). This strain produces more OTC than the parent strain and this overproduction is unstable (Gravius et al., 1993). It therefore seemed possible that pPZG101 had acquired chromosomal sequences from the OTC region. This was tested by hybridizing a Southern transfer with a probe containing the otrB OTC-resistance gene which is part of the biosynthesis cluster (Butler et al., 1989). Fig. 5(b) (track 4) shows that $\mathrm{PPZG} 103$ hybridizes with the otrB probe whereas PPZG101 shows no signal (track 2). Similarly, pP'ZG103, but not pPZG101, hybridized to an $\operatorname{otr} A$ probe (data not shown). DNA of pPZG101 was eluted from a PFGE gel, labelled with digoxigenin and also used as a hybridization probe. Fig. 5(c) (track 4) shows that
pPZG103 hybridizes to pPZG101. Thus, the $1 \mathrm{Mb}$ PPZG103 is a derivative of pPZG101 carrying chromosomal sequences from the OTC region.

When DNA from MV17 was digested with AseI, after a prerun to remove $\mathrm{PPZG} 103$ sequences, no differences in comparison to the parent strain could be seen (data not shown). In particular, when the $\operatorname{otr} B$ gene was used as a hybridization probe, the expected hybridization to a single $795 \mathrm{~kb}$ fragment (Gravius et al., 1993) was seen. Thus, an unaltered copy of the OTC region is probably still present on the chromosome. When total DNA (not prerun) of the strain was digested with $\mathrm{XbaI}$ and, after PFGE, was used for Southern hybridization with the otr $B$ gene, only one fragment of $415 \mathrm{~kb}$ hybridized (data not shown), which was identical in size to that of the parent strain (Gravius $e t$ al., 1993). Thus, the whole of this fragment seems to be present in an unaltered form in PPZG103. The $415 \mathrm{~kb}$ $X b a \mathrm{I}$ fragment showed an increased intensity, suggesting that $\mathrm{pPZG103}$ was present at a copy number several times that of the chromosome. When an AseI digest of total DNA of MV17 was hybridized with an $\operatorname{tr} B$ probe, there was strong hybridization to a fragment of $640 \mathrm{~kb}$ and weaker hybridization to the $795 \mathrm{~kb}$ chromosomal band (data not shown). When labelled DNA from pPZG101 (data not shown) was used as a probe, fragments of sizes corresponding to the plasmid ends (i.e. the AseI-B and AseI-C fragments) hybridized, but no other "junction fragments' could be detected.

\section{Detection of homologous plasmids in other $S$. rimosus strains}

Two other S. rimosus strains, R7 (ATCC 10970, Alačević et al., 1973) and M4018 (Butler et al., 1989) were screened 
for the presence of plasmids. Both contained linear plasmids slightly smaller $(312 \mathrm{~kb})$ than that in $S$. rimosus R6 (data not shown). GLW220, a derivative of M4018 that contains a genetically defined plasmid SR P2' carrying the OTC biosynthesis genes, was also screened. In GLW220 (data not shown), instead of the $312 \mathrm{~kb}$ band there were a major band of $950 \mathrm{~kb}$ and two weaker bands of $1200 \mathrm{~kb}$ and $680 \mathrm{~kb}$. This suggests that the linear plasmid corresponds to SRP2 and that a similar event may have occurred as in MV17.

Total DNA from strain R7 (i.e. consisting of chromosomal and plasmid DNA) was digested with AseI or DraI and subjected to PFGE (data not shown). Southern transfers of the gels were hybridized with digoxigeninlabelled DNA from pPZG101 (data not shown). Three Ase I fragments of $218 \mathrm{~kb}, 64.5 \mathrm{~kb}$ and $29 \mathrm{~kb}$ hybridized the two smaller fragments were indistinguishable in size from the pPZG101 AseI-B and AseI-C fragments. DraI fragments of $187 \mathrm{~kb}, 41 \mathrm{~kb}$ and $36 \mathrm{~kb}$ hybridized, the largest fragment being indistinguishable in size from the pPZG101 DraI-B fragment. These data suggest that the plasmid in $\mathrm{R} 7$ probably has one end similar to the righthand end of pPZG101 (Fig. 2), but that the other end differs.

\section{DISCUSSION}

We constructed a restriction map of the $387 \mathrm{~kb}$ linear plasmid pPZG101 from S. rimosus R6-500 (Fig. 2). The ends of the plasmid were long inverted repeats of at least $95 \mathrm{~kb}$. Long inverted repeats have also been observed in the linear plasmid SCP1 of S. coelicolor A3(2) (Kinashi et al., 1991), but the example of plasmid SLP2 of S. lividans 66 (inverted repeat of $44 \mathrm{bp}$; Chen et al., 1993) shows that long inverted repeats are not a universal property of linear Streptomyces plasmids. It appears that the plasmids in $S$. rimosus $\mathrm{R} 7$ and older $S$. rimosus $\mathrm{R} 6$ derivatives have shorter inverted repeats (if any) than the mapped plasmid. It is likely that the long inverted repeat seen in PPZG101 has arisen during the strain development programme. One possible mechanism to generate the longer repeat would be a recombination event between two copies of a hypothetical linear plasmid ancestor aligned in opposite orientation; such a single cross-over recombination event has been observed between two linear plasmids in Rhodococcus (Kalkus et al., 1993).

The detection of OTC-producing strains lacking plasmid sequences shows that pPZG101 is not essential for OTC synthesis. Although six of thirty-seven mutants tested had part of the plasmid integrated in the chromosome or lacked plasmid sequences altogether, it seems unlikely that the changes in the plasmid are related to the mutant phenotypes; the high frequency of changes probably just reflects plasmid lability. It is likely that pPZG101 is homologous to the sex factor SRP2 in another $S$. rimosus strain (Rhodes et al., 1984). The availability of cured strains of $S$. rimosus R6 will allow experiments to see if pPZG101 also acts as a sex factor.

Four of the mutants had plasmid sequences integrated into the chromosome. Restriction analysis suggested strongly that, in at least three cases, there was still a free plasmid end present. In MV25 (Fig. 3, track 4) two presumed AseI junction bands could be seen, but for 612 and 615 (Fig. 4, tracks 7 and 8) only one junction band was present. If the chromosome of $S$. rimosus $\mathrm{R} 6$ were linear as in S. lividans 66 (Lin et al., 1993) then integration might be explained by exchanging one or both chromosome ends for a plasmid end. Experiments are in progress to construct a restriction map of the chromosome to test this hypothesis.

In one strain (MV17), that overproduces OTC, there is an extra copy of sequences from the OTC region on a prime plasmid (pPZG103) of about $1 \mathrm{Mb}$ that is derived from pPZG101. It is likely that overproduction of the antibiotic is caused by the increased copy number of OTC genes, as other overproducing strains carry reiterations of the OTC region in the chromosome (Gravius et al., 1993). The band intensities suggested that the copy number of the prime plasmid was greater than that of the chromosome. The data would be consistent with a copy number of 3-4, similar to that reported for SCP1 in S. coelicolor A3(2) (Kinashi et al., 1991). The data presented here support the idea that formation of linear plasmids carrying chromosomal genes could play an important role in transferring antibiotic biosynthesis genes between different Streptomyces as suggested by Kinashi et al. (1992). Antibiotic biosynthesis pathways seem to occur as single clusters, which probably carry all the genes necessary for expression in a heterologous host, as demonstrated for actinorhodin biosynthesis by Malpartida \& Hopwood (1984).

A linear plasmid could acquire chromosomal sequences by integration into the chromosome near to genes and subsequent imprecise excision as in the case of the circular $F$ plasmid in E. coli (Hayes, 1968). However, for genes close to a chromosome end of a linear chromosome, a second possibility exists. If integration occurred by a single crossing-over, it would generate a new plasmid containing one plasmid end and one chromosome end. More detailed analysis will show if this model is relevant for the formation of PPZG103.

\section{ACKNOWLEDGEMENTS}

This work was supported by an EC International Scientific Cooperation grant [no. CI1*/0527-C (MB)] (to J.C. and D. H.) and by grant no. 1-08-021 (to D.H.) from the Ministry of Science, Technology and Informatics, Republic of Croatia. We thank the state of Rheinland-Pfalz for a graduate stipendium (to B. G.). We thank Dr G. Tiraby for plasmid pUT1954 and Dr Iain Hunter for providing strains. We are also indebted to Helena Kobelščak and Višnja Horvat for their skilled technical assistance.

\section{REFERENCES}

Alačević, M., Strašek-Vešligaj, M. \& Sermonti, G. (1973). The circular linkage map of Streptomyces rimosus. I Gen Microbiol 77, 173-185. 
Alačević, M., Pigac, J. \& Vesligaj, M. (1978). Different approaches to the gene mapping in Streptomyces rimosus. In Genetics of the Actinamycetales, pp. 65-70. Edited by E. Freerksen, I. Tarnok \& J. H. Thumim. Stuttgart \& New York: Gustav Fischer Verlag.

Binnie, C., Warren, M. \& Butler, M. J. (1989). Cloning and hetcrologous expression in Streptomyces lividans of Streptomyces rimosus genes involved in oxytetracycline biosynthesis. $J$ Bacteriol 171, $887-895$.

Butler, M. J., Friend, E. J., Hunter, I. S., Kaczmarek, F. S., Sudgen, D. A. \& Warren, M. (1989). Molecular cloning of resistance gene and architecture of a linked gene cluster involved in the biosynthesis of tetracycline by Streptomyces rimosus. Mol \& Gen Genet 215, 231238

Chardon-Loriaux, I., Charpentier, M. \& Percheron, F. (1986). Isolation and characterization of a linear plasmid from Streptomyces rimo.izs. FEMS Microbiol Lett 35, 151-155.

Chen, C. W., Yu, T.-W., Lin, Y.-S., Kieser, H. M. \& Hopwood, D. A. (1993). The conjugative plasmid SLP2 of Streptomyces lividans is a $50 \mathrm{~kb}$ linear molecule. Mol Microbiol 7, 925-932.

Cullum, J., Flett, F., Gravius, B., Hranueli, D., Miyashita, K., Pigac, J., Rauland, U. \& Redenbach, M. (1991). Analysis of amplifications and deletions in Streptomyces species. In Genetics and Product Formution in Streptomyces, pp. 265-272. Edited by S. Baumberg, H. Krügel \& D. Noack. New York \& London: Plenum Press.

Friend, E. J., Warren, M. \& Hopwood, D. A. (1978). Genetic evidence for a plasmid controlling fertility in an industrial strain of Streptomyces rimosus. J Gen Microbiol 106, 201-206.

Gravius, B., Bezmalinović, T., Hranueli, D. \& Cullum, J. (1993). Genetic instability and strain degeneration in Streptomyces rimosus. Appl Eniron Microbiol 59, 2220-2228.

Gravius, B., Cullum, J. \& Hranueli, D. (1994). High G + C-content DNA markers for pulsed-field gel electrophoresis. BioTechniques 16, 52

Hanafusa, T. \& Kinashi, H. (1992). The structure of an integrated copy of the giant linear plasmid SCP1 in the chromosome of Streptamyces coelicolor 2612. Mol \& Gen Genet 231, 363-368.

Hayes, W. (1968). The Genetics of Bacteria and Their Viruses, 2nd edn. Oxford: Blackwell Scientific Publications.

Hershberger, C. L., Arnold, B., Larson, J., Skatrud, P., Reynolds, P., Szoke, P., Rosteck, P. R., Jr, Swartling, J. \& McGilvray, D. (1989). Role if giant linear plasmids in the biosynthesis of macrolide and polyketide antibiotics. In Genetics and Molecular Biology of Industrial Microorganisms, pp. 147-155. Edited by C. L. Hershberger, S. W. Queener \& G. Hegeman. Washington, DC: American Society for Microbiology.

Hirochika, H., Nakamura, K. \& Sakaguchi, K. (1984). A linear DNA plasmid from Streptomyces roche $i$ with an inverted terminal repetition of 614 base pairs. EMBO J 3, 761-766.

Hopwood, D. A. \& Wright, H. M. (1976). Genetic studies on SCP1prime strains of Streptomyces coelicolor A3(2). J Gen Microbiol 95, $107-120$.

Hopwood, D. A., Bibb, M. J., Chater, K. F., Kieser, T., Bruton, C. J., Kieser, H. M., Lydiate, D. J., Smith, C. J., Ward, J. M. \& Schrempf, H. (1985). Genetic Manipulation of Streptomyces: a Laboratory Manual. Norwich: The John Innes Foundation.

Hranueli, D., Pigac, J. \& Vešligaj, M. (1979). Characterization and persistence of actinophage RP2 isolated from Streptomyces rimosus ATCC 1(1970. J Gen Microbiol 114, 295-303.
Kalkus, J., Dörrie, C., Fischer, D., Reh, M. \& Schlegel, H. G. (1993). The giant linear plasmid pHG207 from Rhodococcus sp. encoding hydrogen auxotrophy: characterization of the plasmid and its termini. J Gen Microbiol 139, 2055-2065.

Keen, C. L., Mendelovitz, S., Cohen, G., Aharonowitz, Y. \& Roy, K. L. (1988). Isolation and characterisation of a linear plasmid from Streptomyces clavuligerus. Mol \& Gen Genet 212, 172-176.

Kinashi, H. \& Shimaji-Murayama, M. (1991). Physical characterization of SCP1, a giant linear plasmid from Streptomyces coelicolor. I Bacteriol 173, 1523-1529.

Kinashi, H., Shimaji, M. \& Sakai, A. (1987). Giant linear plasmids in Streptomyces which code for antibiotic synthesis genes. Nature 328, 454-456.

Kinashi, H., Shimaji-Murayama, M. \& Hanafusa, T. (1991). Nucleotide sequence analysis of the unusually long terminal inverted repeats of a giant linear plasmid, SCP1. Plasmid 26, $123-130$

Kinashi, H., Shimaji-Murayama, M. \& Hanafusa, T. (1992). Integration of SCP1, a giant linear plasmid, into the Streptomyces coelicolor chromosome. Gene 115, 35-41.

Lin, Y.-S., Kieser, H. M., Hopwood, D. A. \& Chen, C. W. (1993). The chromosomal DNA of Streptomyces lividans 66 is linear. Mol Microbiol 10, 923-933.

Malpartida, F. \& Hopwood, D. A. (1984). Molecular cloning of the whole biosynthetic pathway of a Streptomyces antibiotic and its expression in a heterologous host. Nature 309, 462-464.

Pigac, J. \& Alačević, M. (1979). Mapping of oxytetracycline genes in Streptomyces rimosus. Period Biol 81, 575-582.

Pigac, J., Hranueli, D., Smokvina, T. \& Alačević, M. (1982). Optimal cultural and physiological conditions for handling Streptomyces rimosus protoplasts. Appl Environ Microbiol 44, 1178-1186.

Rathos, M. J., Verma, N. C. \& Notani, N. K. (1989). Separation by pulsed-field gradient gel electrophoresis of giant linear plasmids from antibiotic-producing strains of Streptomyces and Nocardia. Curr Sci 58, 1235-1239.

Reynes, J. P., Calmels, T., Drocourt, D. \& Tiraby, G. (1988). Cloning, expression in Escherichia coli and nucleotide sequence of a tetracycline-resistance gene from Streptomyces rimosus. J Gen Microbiol 134, 585-598.

Rhodes, P. M., Hunter, I. S., Friend, E. J. \& Walker, M. (1984). Recombinant DNA methods for the oxytetracycline producer Streptomyces rimosus. Biochem Soc Trans 12, 586-587.

Sakaguchi, K. (1990). Invertrons, a class of structurally and functionally related genetic elements that include linear DNA plasmids, transposable elements and genomes of adeno-type viruses. Microbiol Rev 54, 66-74.

Salas, M. (1991). Protein-priming of DNA replication. Annu Rev Biochem 60, 39-71.

Sambrook, J., Fritsch, E. F. \& Maniatis, T. (1989). Molecular Cloning: a Laboratory Manual, 2nd edn. Cold Spring Harbor, NY: Cold Spring Harbor Laboratory.

Vivian, A. \& Hopwood, D. A. (1973). Genetic control of fertility in Streptomyces coelicolor A3(2): new kinds of donor strains. $J$ Gen Microbiol 76, 147-162.

Wright, L. F. \& Hopwood, D. A. (1976). Identification of the antibiotic determined by the SCP1 plasmid of Streptomyces coelicolor A3(2). J Gen Microbiol 95, 96-106.

Received 4 March 1994; accepted 13 April 1994 